\title{
Expectations, Satisfaction and Professional Achievement. An Analysis of their Relation in light of a New Systemic Paradigm: The Three- Dimensional Spiral of Sense
}

\author{
Miriam Aparicio \\ National Council of Scientific Research (CONICET). National University of Cuyo. Mendoza, Argentina
}

\begin{abstract}
This research has been done in the field of Education, Sociology and Social and Organizational Psychology. Issues are taken up from two research studies carried out with researchers and PhDs from different disciplinary fields and national contexts. The relationship between Expectations, levels of Satisfaction and Professional Achievement are analyzed in light of different theories: Expectancy-Valence, Attributional theories, Education theories such as Consumption or Investment / Human Capital and the theory of Anomy. The methodology utilized was quantitative-qualitative: two questionnaires, one semi-structured survey including open phrases which allowed actors to speak freely, one interview and, in the case of the French-Argentine research with PhDs, a special qualitative technique was applied: hierarchical evocation. This allowed us to determine which aspects related to professional pathways (objective and subjective) formed part of the "core" of social or shared representations and which were secondary aspects at the periphery of said core. Our findings show non-linear relationships between study variables - Expectations, Satisfaction and Achievement - and self-sustained interplay along three levels: micro individual, meso organizational and macro social. These are interpreted in light of a new systemic paradigm in human and social sciences, a paradigm which the author defines as "The Three-Dimensional Spiral of Sense".
\end{abstract}

Keywords: Expectations, Satisfaction, Professional Achievement, PhDs, Scientists, New Paradigm

\section{Introduction}

\section{Framework}

The theoretical framework refers to theories associated with achievement and the difficulties that could arise and the academic and workplace levels. Theories of achievement/failure are included but will not be detailed here. It is important to note that we have carried out research over the course of twenty years at two national universities in Argentina and at a diverse array of workplace institutions, in which levels of achievement have been the dependent variables of the different models. We have studied numerous populations: university graduates, dropouts, those who have been delayed in the academic system, university and secondary school professors, and private and public workplaces, among others (a synthesis of these theoretical references can be found in Aparicio 2005, 2007 a and b; 2014; $2015 a$ and b).

We will make brief reference to two theories, always referring back to the founding fathers. On the one hand, to the Expectancy-Valence Theory (Feather \& Davenport, 1982), linked to Burnout syndrome or workplace fatigue (Freudenberger, 1975; Maslach, 1976; Maslach \& Jackson, 1986; Pines \& Aronson, 1988; Brill, 1984); fatigue observed here by way of Expectations/Anomy. On the other hand, to the models of Consumption/Investment, related to the Theory of Human Capital (Becker, 1964, Coleman, 1966).

Burnout syndrome is associated with the devaluation of degrees in the labor market, which is in turn associated with more extended levels of failure (at least relative failure, from the objective and subjective points of view). Said devaluation and the new labor market have an important impact on personal and institutional identity (Aparicio, $2015 \mathrm{~d}$, Silva \& Aparicio, 2015).

However, although Educational Sociology (Boudon, 1973; Frisch, 1972; Anderson, 1961) and Economics of Education (Jarousse, 1984; Levy-Garboua; 1976, 1977) had anticipated the situation during the 1970s, very few studies associated burnout syndrome in the field of Health with Education and, more specifically, with the level of education achieved and the 
Professional Expectations related to such level (the higher the level of education, the higher the expectations). The lack of research regarding this paradoxical issue - as Anderson (1961) points out, the level of education progresses gradually whereas the market shows abrupt changes and worrying indicators (structural underemployment, unemployment, labor instability, difficulties for promotion or mobility, etc., with consequences for achievement and even, at times, for health) led us to carry out this work. The author has been working on this issue since the 1980s within the framework of complementary research. Thus, she intends to surpass the diagnosis with "figures" or statistics on Education and Health which account for a given situation but are not themselves able to explain the "causes" or much less "comprehend" the "reasons" underlying some associated syndromes and variables. She is not only interested in determining the inputs and outputs of the school system (graduation, dropout and delay rates) and of the employment system (including Health), but also, and fundamentally, in investigating the processes and/or consequences intervening in professional "Achievement" (in the broad sense and in terms of different variables: Professional Mobility, Satisfaction and Professional Achievement, among others).

Finally, the findings are interpreted in light of the author's new systemic theory: The Three- Dimensional Spiral of Sense.

A brief description of the two main theories employed here:

\section{Expectancy-Valence Theory}

A person's motivational drive to act is determined by his/her expectations of success or failure and the subjective valences attributed to success or failure. This theory is generally applied to achievement behaviors, broadly speaking. In this study we take into account professional "achievements". Atkinson (1964) states that "Achievement Motivation is the result of the tendency to approach success and the tendency to avoid failure. Both are determined by the probability of success or failure, the cause for success or failure and the perceived value of success or failure." (García Rodríguez, 1993: 177, t.n.). As regards the Expectancy-Valence Model, "...expectations and values combine to determine the intensity with which a certain act is performed".

The underlying hypothesis is as follows: "...the negative feeling of depression and pessimism subsequent to the failure to get a job (for example) will be deeper among those who consider a job attractive, who have great expectations for getting a job, and who are highly motivated to look for a job, as compared to those who have lower valence, expectations and motivation values... This prediction applies to every stage in the job search." (García Rodríguez, 1993: 180, t. n.)

Weiner (1986) completes Atkinson's theory stating that success or failure expectations for achievement behavior are determined by attributional processes, i.e., they depend on the individuals' achieved status and beliefs as regards the result of a specific achievement. Such causes for success or failure are defined along two dimensions: unstable-stable and internal-external .

Briefly, levels of Achievement (observed in the research studies addressed here) and Workplace Satisfaction reached are dependent on the Expectations, Aspirations and Values given priority in one's life (McClelland, 1953, 1961), as well as on the level of control that they have over one's behavior (attributional theories). As Seligman $(1975,1981)$ states, 'low levels of expectation mean low levels of desperation.' This could explain how, in our findings (from multiple research projects over the course of thirty years): a) no linear relationship emerges among variables; b) significant differences are observed according to disciplinary field: soft sciences versus hard sciences, generally, and, more specifically, in fields such as Education - where values such as service and dedication are given priority - and in other fields (Sciences of Management and Administration / Engineering) - where power, prestige and economic achievement are prioritized.

\section{2. "Consumption-Investment" Models}

Said vocational/professional options are related, from the vantage point of theories associated with the Economy and Sociology of Education, to profiles of different variables, with self-evaluation/self-esteem/self-image (Bandura, 1977, 1982) here carrying important weight; evaluation that leads to institutional "self-selection". That is to say, those who consider themselves more capable and have more financial possibilities, generally steer themselves toward demanding careers that provide a promising workplace future (investment model); that is, careers that respond to their expectations. Those having the opposite profile (consumption), eliminate themselves from careers which they would have liked to enter after analyzing, from their perspective, their personal, sociocultural and financial possibilities. They opt for other careers to which they are also attracted, more related to the humanities, and feel satisfied carrying out their métier. Nevertheless, this does not imply 
that they demand Professionalization (Bourdoncle, 1993, 2000; Bourdoncle \& Demailly, 1998) and are unaware of identity strategies which they must use to remain in the system (Goffman, 1963).

Lastly, in the comparative French-Argentine study carried out with PhDs (Aparicio \& Cros, 20015c), differences between the two nationalities emerge which demonstrate the interaction between micro levels (individuals), the academic-scientificworkplace organizations in which they are inserted (meso level) and the macro national level which conditions their possibilities for achievement according to the expectations held.

\section{Methodology}

Methodology is detailed for both research studies addressed.

\subsection{Research with PhDs (Aparicio 2005-2009/2016)}

2.1.1. Methods: The quantitative-qualitative method was applied. This study refers only to the qualitative method.

2.2.2. Participants: PhDs in Education at the Universidad Nacional de Cuyo (National University of Cuyo, 2005-2009), and doctoral students of Adult Education at Cnam (National Conservatory of Arts and Crafts, France). Two research laboratories took part in this work: the Laboratorio de Investigaciones en Educación (Education Research Laboratory, Conicet/UNCuyo, Argentina) and the CRF (Centre de Formation sur la Recherche, Cnam, France). Currently, this research - which obtained an award from the City of Paris - has been extended to other universities in France. We expect to find different profiles according to the work/professional contexts in which individuals are situated, together with the differences of the respective contexts in our country, with contributions from the micro level: the problems, values and priorities appearing in the social representations shared by each of these groups. This will allow us to observe different institutional, personal and professional identities, as well as different aspects along professional careers. Group samples included were significant and allow for quantitative treatment of the data.

2.2.3. Materials: Quantitative and qualitative techniques were applied. We also used "hierarchical evocation" and lexicometric analysis techniques (See Aparicio \& Cros, $2015 \mathrm{c}$ ). The latter allowed us to show which representations are part of the "core" of doctoral training in each of the national groups, what their most evident differences are and in what way they experience their professional practice according to their expectations.

\subsection{Study of scientific researchers (Aparicio, 2014)}

2.1.1. Participants: A stratified sample was taken from universities and different disciplines, based on a population of researchers from the Cuyo region ( $N=355$ UID - Research \& Development Units) ( $5 \%$ error margin). At this first stage, the researchers were from the Universidad Nacional de Cuyo ( $N=53$ Research Units): one Director and various members of each Research Unit.

2.1.2. Techniques: Quantitative techniques were used. Two questionnaires were employed: 1) The questionnaire concerning Research and Development (R\&D units) was answered only by Directors, who provided information about that unit (human and financial resources, scientific exchanges, age of the research units, national and foreign income sources and the product, among others). 2) The Core Members questionnaire provided data and opinions and referred to the social role of individuals working in the R\&D units, together with information about working atmosphere, perceptions about jobs and opinions regarding budget, resources and services, power and influence, research work organization, etc.

Grids were established: seven Central Satisfaction Grids, one Product Grid and one Professional Mobility Grid were developed.

As regards the Satisfaction Grids, items were based on the Liker 1-5 scale, with 5 being the most positive and 1, the most negative. The subject was to give his/her opinion about each pair of opposite statements $(X-Y)$, grading them as follows: 5) $X$ is applicable, 4) tendency to $X, 3$ ) neutral, 2) tendency to $Y, 1) Y$ is applicable.

Indexes were made by adding up the total score for each of the items, divided by the figure resulting from 5 times the number of items.

\section{Results}

4.1. Research carried out with PhDs from France and Argentina from different disciplinary fields 
Findings are presented in two sections: quantitative (descriptive plan, correlational and explanatory) and qualitative (For a detailed analysis, see Aparicio \& Cros, 2015c).

As we could observe, there are no obvious differences between the French and Argentine groups. Doctoral training is valued by both groups; that is, although the general idea is that $\mathrm{PhD}$ degrees are being devalued, subjectively, $\mathrm{PhDs}$ are quite satisfied. They expect improvements in their future work life, thus a positive view prevails. On the contrary, graduates in education without a PhD degree do not have the same view. Briefly, doctoral education (in Argentina) is still considered an "add-on". The strongest claim against the labor market lies with a lack of recognition, especially among French PhDs. Comparatively, the Argentine group has higher expectations as regards the degree. The "plafond" effect or PhD saturation (particularly in some disciplinary fields), evident in various developed countries, also appears in our research.

We also observe that those who chose academic programs such as Education, within the "Consumption" model, show high degrees of satisfaction despite having less prestige, power and even recognition in the professional field. In effect, their expectations did not include these aspects as goals. On the contrary, they chose other values such as service, dedication, interaction and the development of others. This means that, despite being thrust into sometimes unfavorable social contexts, they feel satisfied, though this does mean that they do not voice concerns to the national system. However, these concerns are of a different magnitude and sense than those voiced by PhDs in the field of Management/Administration who demand education in collective and social competencies and greater levels of recognition. Our findings show institutional identities (meso level) and professional identities (micro level).

At the theoretical level, this research allowed us to: a) show the differences and similarities shared by both groups of doctors recently inserted in the professional field; $b$ ) supervise the heuristic implications of some explanatory and comprehensive methods; c) go deeper into the relationship between higher education and occupational market from an interdisciplinary perspective, as well as into the transformations in the professional world, new demands and their impact at the identity level. In fact, the study showed more accomplished "identities", other identities blocked due to lack of recognition, and others in search of some type of transformation; d) on the one hand, identify differences in Expectations and Achievement Valuation (Satisfaction) according to disciplinary field and, on the other hand, identify different demands made of educational institutions which call for revising some "institutional identities" so as to incorporate new fields and/or factors needed in the current Market without leaving behind the traditional "disciplinary" aspects; e) and finally, levels of Satisfaction reached are, in large part, associated with expectations, as they did not always have linear relationships with Position or Professional Mobility (here, factors of achievement).

Our findings show the interplay between individuals and institutional and macro-national contexts and the non-existence of general theories; on the contrary, we might speak of "situated" theories, as the author suggests.

\subsection{Research carried out with scientific researchers}

Levels of satisfaction, it was observed, are not independent from professional mobility or from the associated fields of specializations: a) A significant association exists between professional mobility and workplace satisfaction, with no distinction between "hard" and "soft" sciences (disciplinary fields); b) Making a distinction between the two types of sciences, we detect that there exists a different association between factors playing a role in the variables Workplace Satisfaction and Professional mobility in both "hard" and "soft" sciences. In other words, the most movable subjects in "hard" sciences find satisfaction in some aspects -typically present in their discipline- which are different from those in "soft" sciences (Crane, 1972; Gaston, 1972). There is only one aspect in common: researchers from both fields feel they are not satisfied with leadership in their teams.

In the field of "hard sciences", the level of satisfaction is lesser and there are more demands of the system. This more marked non-conformity and fatigue is also observed among those who ascended more in the workplace (Heintz, 1970; Cole S. \& Cole, J. (1967). This result could be interpreted in light of the "Expectancy-Valence Theory (Weiner, 1980; Feather \& Davenport, 1981) and of the Consumption-Investment theories and Human Capital theories. From the "investment"model point of view (Becker, 1964), those who have reached a higher position and have made greater effort towards higher achievements may expect more benefits, many of which are associated with management.

As was mentioned previously: the hard sciences (Engineering in particular but also Administration sciences) attract more favored student bodies from the sociocultural and economic point of view, students who know from the start that they will not have to work while studying. Added to this is a positive view of themselves (high self-esteem, self-image, self-efficacy: 
Bandura, 1977, 1982) and their capacity to reach their goals, goals which tend to be clearer than those set by students of the humanities (among them, Education; an academic program which in our context is not a first option). Lastly, they are inserted in more demanding academic programs and expect a better workplace future and possibilities for professional and economic growth. Nevertheless, as they as progress through the hierarchy, they face more demands to manage with insufficient financial resources and, sometimes, do not have sufficient training in management and its related competencies. Thus, non-conformity and fatigue emerge.

Additionally, the relationship between Professional Mobility or Status reached by scientific groups from different disciplinary fields and Satisfaction is not linear (House \& Wigdor (1967). On the contrary, in said fields, greater professional development goes hand in hand with greater degrees of non-conformity.

This reveals a spiraled movement in which individuals' frustrated Expectations appear at the base of the issue of scientific micro-organizations and, deep down, the macro-national scientific system. Self-sustained relationships between individuals and contexts are clearly observed, showing important aspects needed for institutional innovation which have at their core greater levels of professional satisfaction.

\section{Conclusion}

Observing unexpected relationships between academic, workplace and scientific variables over the course of thirty years of research within the national scientific system of Argentina has led the author to establish a systemic theory with a different foundation than the classic biological systemism and administrative systemism of the 20th century (2015 a and b). This theory, "The Three-Dimensional Spiral of Sense", refers to the fact that in order to find the "reasons" underlying statistics at the comprehensive-qualitative level, it is necessary to study individuals, individuals who were lost with the prevalence of structures in hyperfunctionalist and hyperculturalist positions (Bourdieu, 1976).

In the cases analyzed (researchers/scientists and PhDs), individuals' unsatisfied expectations emerge at the base of nonconformity in organizations, with effects on the macro national system (frequent demonstrations by researchers, union demands, non-conformity, pessimism, anomy). This macro-national system - as its characteristics are made known to young people having to choose between starting a "Research Career" or doctoral programs and society as a whole returns, at the same time, to the individual. In effect, we observe a drop in expectations and/or feedback of nonconformity/fatalism, creating fragile micro and institutional identities. Recovering an understanding of the "meaning" of the human behavior at the core of statistics and even of national policy become essential. Recent political experience in the US and in Europe, marked by a certain xenophobia, places "frustrated expectations" as they relate to "promises" at the base of abrupt changes in political leanings at the national level, with impacts felt even at the international level, compromising the global system.

We hope our findings encourage academic institutions and workplace organizations (considered in the broad sense) to revise their leadership standards and the profiles they desire, recovering the individual and, with him, the meaning behind his behavior This "meaning", under the effects of aggregation, impacts both the meso and macro levels. Strictly speaking, our findings encourage the incorporation of the individual in his context, without neglecting either.

\section{References}

[1] Anderson, C. (1961). A Skeptical on Education and Mobility. In H. Halsey, J. Floud \& C. Anderson (1961). Education, Economy and Society (164-179). New York: The Free Press.

[2] Andrews et al. (1979). Scientific Productivity. Cambridge University Press/UNESCO.

[3] Aparicio, M. (2005). Les facteurs psychosociaux en relation avec la réussite universitaire et professionnelle. 2e thèse de doctorat. Doctorat en sciences de l'éducation, 3 vol. Université René Descartes. Paris V. Sorbonne, France. Mention: Très honorable avec félicitations du jury á l'unanimité (published as a book, 608 p.).

[4] Aparicio, M. (2007a). Les facteurs psychosociaux à la base de la réussite universitaire et professionnelle : aspects psychologiques et organisationnels. HDR. Psychologie. Université de Lille3. France.

[5] Aparicio, M. (2007b). Mobilité et réussite universitaires et professionnelles. Du niveau macro au niveau micro. HDR en Sciences de l'éducation. Université Paris X, Nanterre, France. 
[6] Aparicio, M. (2009c). Les facteurs psychosociaux et la réussite universitaire et professionnelle. ANRT. Presses de l'ANRT, Lille, 469 p., 126 p. Annexes.

[7] Aparicio, M. (2014). University Drop-Outs. A Systemic Play of Subjects, Institutions and Macro Contexts, Journal of Educational and Social Research, 4(2), Special Issue, April.

[8] Aparicio, M. (2012). Trajectoires universitaires/professionnelles et identité. In J. Clénet, Ph. Maubant, D. Poisson (Eds.), Formations et professionnalisations: à l'épreuve de la complexité (195-229). Paris: L'Harmattan,

[9] Aparicio, M. (2012c). Crise d'identité et devenir professionnel des étudiants qui sont engagés dans un doctorat en éducation/formation. Une approche comparative franco-argentine. Biennale internationale de l'éducation, la formation et des pratiques professionnelles, Cnam, Paris. July 4th-6th.

[10] Aparicio, M. (2014 a). Satisfaction, Professional Mobility and Leadership in Academic-Scientific Organizations, Journal of Health Science, 2(3), 135-145.

[11] Aparicio, M. (2014 b). Postgraduate Level and its Impact on Academic Studies and Professional Careers, Social and Job Mobility and Identity. A Study about PhD Graduates and PhD Students at UNCuyo, in the Light of a sui generis Paradigm, Journal of Educational and Social Research, 4, 2, Special Issue - April.

[12] Aparicio, M. (2015 a).Towards a sui generis systemic theory: The Three-Dimensional Spiral of Sense. A Study in Argentina Applied to Identity and Professionalization (Article 1). Asian Academic Research Journal of Social Sciences \& Humanities (AARJSH), vol 2, issue 7 (December 2015), 246-282.

[13] Aparicio, M. (2015 b). The Theory of the Three-Dimensional Spiral of Sense: An Application with special Reference to Identity and Professionalization in other Disciplinary Areas (Article 2). Asian Academic Research Journal of Social Sciences \& Humanities (AARJSH), vol 2, issue 7 (December 2015), 194-245.

[14] Aparicio, M. \& Cros, F. (2015 c). Trajectoires et identités. Un avenir incertain pour les docteurs? Une étude comparative franco-argentin. Paris: L'Harmattan.

[15] Aparicio, M. (2015 d). Identity, Weakening and Professionalization. A Study on Graduate and Postgraduate Students (1987-2002) in the Light of the Three-Dimensional Spiral of Sense Theory. In A.M. Silva \& M. Aparicio.International Handbook of Professional Identities. USA: Scientific Academic Publishing.

[16] Atkinson, J. (1964). An Introduction to Motivation. New York Van Nostrand Reinhold Company.

[17] Bandura, A. (1977). Self-efficacy: Toward a Unifying Theory of Behavioral Vhange. Psychological Review, 84(2), 191.

[18] Bandura, A. (1982). Self-efficacy Mechanism in Human Agency. American Psychologist, 37, 122-147.

[19] Becker, G. (1964). Human Capital. New York/London: Columbia University Press.

[20] Boudon, R. (1973). L'inégalité des chances. La mobilité sociale dans les sociétés industrielles. Paris: PUF.

[21] Boudon, R. (1977). Effets pervers et ordre social. Paris: PUF.

[22] Bourdieu, P. (1976). The Specificity of the Scientific Field and the Social Conditions of the Progress of Reason. Social Science Information, 14(6), 19-47.

[23] Bourdoncle, R. (1993). La professionnalisation des enseignants: les limites d'un mythe, Revue française de pédagogie, 105, 83-119.

[24] Bourdoncle, R. (2000). Autour du mot professionnalisation, formes et dispositifs, Recherche et Formation, 35, 117132.

[25] Bourdoncle, R. \& Demailly, L. (1998) (comp.). Les professions de l'éducation et de la formation. Paris: Septentrion.

[26] Brill, P.L. (1984). The need for operational definition of burnout. Family and Community Health, 6, 12-24.

[27] Cole S. \& Cole, J. (1967). Scientific Output and Recognition. A Study in a Reward System in Science. American Sociological Review, 32, 377-390.

[28] Coleman, J. et al. (1966). Equality of Educational Opportunity. U.S. Departement of Health Education and Welfare.

[29] Crane, D. (1972). Invisible Colleges. Chicago: University Chicago Press. 
[30] Dubar, C. (1995). Pour une approche compréhensive à la promotion sociale. Pour 148.

[31] Etzioni, A. (1969). The Semi-Professions and Their Organizations. New York: The Free Press.

[32] Feather, N. \& Davenport, P. (1981). Unemployment and Depressive Effect: a Motivational and Attributional Analysis. Journal of Personality and Social Psychology, 41(3), 422-436.

[33] García Rodríguez, Y. (1993). Desempleo. Alteraciones psicológicas, Promolibro, Valencia.

[34] Gaston, J. (1972). Communication and the Reward System of Science: A Study of a National Invisible College. In Halmos, P. (ed.). The Sociology of Science. Sociological Review Monograph, 18, 25-41.

[35] Goffman, E. (1963). Stigma. Prentice Hall. Traduction française Stigmates. Les usages sociaux des handicaps, Paris :Minuit, 1975.

[36] Frish, J. (1972). L'importance des diplômes pour la promotion. Économie et Statistique, 21, 33-44.

[37] Jarousse, J-P. (1984). Les contradictions de l'université de masse dix ans après. R. Française Sociol, 24(2), 192.

[38] Halsey, H., Floud, J. \& Anderson, C. (1961). Education, Economy and Society. New York: The Free Press.

[39] Heintz, P. (1970). Hacia un paradigma sociológico del desarrollo en América Latina. Buenos Aires: Instituto.

[40] House \& Wigdor (1967). Herzberg's Dual-Factor Theory of Job Satisfaction and Motivation: A Review of the Evidence and the Criticism. Personal Psychology, 20, 369-389.

[41] Lévy-Garboua, L. (1976). Les demandes de l'étudiant ou les contradictions de l'université de masse, $R$. Française de Sociol., 17(1), 53-80.

[42] Lévy-Garboua, L. (1977). Les demandes de l'étudiant ou les contradictions de l'Université de masse: réponse aux commentaires, $R$. Française de Sociol., 19(1), 147-156.

[43] Maslach, C. (1976). Burn-out. Human Behavior, 9(5), 16-22.

[44] Maslach, C. \& Jackson, S.R. (1986). The Burnout research in the social services: a critique, Special issues: Burnout among social workers, Journal of Occupational Behaviour, 1, 95-105.

[45] McClelland, D., Atkinson, J. W., Clark, R. A. \& Lowell, E. (1953). The achievement motive. New York: Appleton Century Crofts. Cit. en Huertas, J. A. (2006). Las teorías de la motivación, desde el ámbito de lo cognitivo y lo social. Recuperado de http:// sohs.pbs.uam.es/webjesus/motiv_ev_autorr/.../teorias.pdf.

[46] McClelland, D. (1961). The Achieving Society. Princeton: Van Nostrand Company, Inc.

[47] Pines, A. M. \& Aronson, E. (1988). Career burnout: Causes and Cures. New York: Free Press.

[48] Seligman, M. (1975). Helplessness: On Depression, Development, and Death. San Francisco : W. H. Freeman.

[49] Seligman, M. (1981). Indefensión. Madrid: Debate.

[50] Silva, A.M. \& Aparicio. M. (2015 b). International Handbook of Professional Identities. New York : Scientific Academic Publishing.

[51] Weiner, B. (1986). An attributional theory of motivation and emotion. New York: Springer-Verlag. 